\title{
PERAN DINAS SOSIAL DALAM PEMBERDAYAAN PENYANDANG DISABILITAS DI KOTA BINJAI
}

\author{
Suhailah Hayati, Maulana Andi Surya \\ Program Studi Pengembangan Masyarakat Islam, Fakultas Dakwah dan \\ Komunikasi, Universitas Islam Negeri Sumatera Utara
}

\begin{abstract}
Abstrak: Tujuan penelitian ini untuk mengetahui peran Dinas Sosial dalam pemberdayaan penyandang disabilitas. Penelitian ini menggunakan tipe penelitian kualitatif. Teknik pengumpulan data berupa teknik wawancara, studi pustaka, observasi dan dokumentasi. Teknik tringulasi data sumber digunakan sebagai teknik keabsahan data. Hasil penelitian ini menunjukkan bahwa peran Dinas Sosial dalam pemberdayaan penyandang disabilitas fasilitatif telah berperan cukup baik namun belum secara maksimal. Hal ini ditandai dengan pelatihan bantuan sosial yang diberikan belum merata, masih banyak penyandang disablitas yang belum merasakan. Sehingga perlu dilakukan evaluasi terhadap peran Dinas Sosial dalam pemeberdayaan penyandang disabilitas.
\end{abstract}

Kata kunci: Peran, Pemberdayaan, Disabilitas

\section{PENDAHULUAN}

Pembangunan nasional merupakan usaha peningkatan kualitas manusia dan masyarakat Indonesia secara berkelanjutan dengan memanfaatkan kemajuan ilmu pengetahuan dan teknologi serta memperhatikan tantangan perkembangan global. Selain itu, tujuan Pembangunan Nasional untuk mewujudkan masyarakat adil dan makmur yang merata material dan spiritual, serta menjalankan roda perekonomian guna mewujudkan kesejahteraan sosial. Sesuai dengan Pasal 33 UUD 1945 dimana sebagai dasar untuk mewujudkan keadilan, kesejahteraan dan kemakmuran rakyat melalui peranan dan keberpihakan negara dalam meningkatkan taraf hiduprakyat.

Tujuan pembangunan nasional dan Pasal 33 UUD 1945 tersebut akan berhasil tercapai apabila pemerintah dan masyarakat saling bersinergi dalam proses pembangunan, termasuk di bidang kesejahteraan sosial. Dalam permasalahan ini yang cukup krusial dalam bidang kesejahteraan sosial berada pada kasus penanganan anak jalanan, dimana hampir di setiap daerah jumlah anak jalanan mengalami peningkatan.

Akan tetapi melihat pada zaman sekarang sebagian masyarakat dalam lingkaran kemiskinan sebagai penyebab utama munculnya penyandang disabilitas 
yang dalam penghidupannya masih memerlukan bantuan dari pihak pemerintah agar kiranya dapat berkehidupan normal. Maka dari itu perlu kebijakan dan program untuk menunjang masyarakat agar sejahtera dari segi sosial.

Binjai merupakan kota dengan jumlah penduduk 267.901 jiwa dengan kepadatan penduduk 2.961,86 jiwa dari $\mathrm{km}^{2}$ pada april 2016. Tenaga kerja produktif sekitar 160.000 jiwa. Banyak juga penduduk Binjai yang bekerja di Medan karena transportasi dan jarak yang relatif dekat. ${ }^{1}$ Dari 267.901 jiwa jumlah penduduk di Kota Binjai ada sebanyak 290 orang tercatat sebagai penyandang disablitas yang masuk dalam daftar pemilih tetap hasil perbaikan (DPTHP-2). Rinciannya, tuna daksa 115 orang, tuna netra 29 orang, tuna rungu/wicara 33 orang, tuna grahita 86 orang dan disabilitas lainnya 27 orang. $^{2}$

Istilah penyandang disabilitas sering digunakan untuk menyebut sekelompok masyarakat yang memiliki gangguan mental, kelainan atau bahkan kehilangan fungsi organ tubuhnya. Kecacatan tersebut seharusnya tidak menjadi halangan bagi penyandang disabilitas untuk memperoleh hak hidup yang layak dan hak mempertahankan kehidupannya. Penyandang disabilitas pada dasarnya bukanlah merupakan kaum minoritas dan wajib mendapatkan perhatian yang sama dengan masyarakat normal lainnya. Hal ini dipertegas menurut UndangUndang Nomor 8 tahun 2016 tentang Penyandang Disabilitas bahwa :

"Negara Kesatuan Republik Indonesia menjamin kelangsungan hidup setiap warga negara, termasuk para penyandang disabilitas yang mempunyai kedudukan hukum dan memiliki hak asasi manusia yang sama sebagai Warga Negara Indonesia dan sebagai bagian yang tidak terpisahkan dari warga negara dan masyarakat Indonesia merupakan amanah dan karunia Tuhan Yang Maha Esa, untuk hidup maju dan berkembang secara adil dan bermanfaat".

Masyarakat berasumsi bahwa seorang penyandang disabilitas tidak akan mampumelakukan pekerjaan seefektif seperti karyawan lain yang bukan penyandang disabilitas. Sehingga bagi para penyedia lapangan pekerjaan,

\footnotetext{
${ }^{1}$ http://www.binjaikota.go.id, diaksespadahariRabu, tanggal 20-03-2019, pukul 17:33 WIB

${ }^{2}$ http://medanmerdeka.com/pemilu/290-penyandang-disabilitas, diaksespadahariRabu, 2003-2019, pukul 17:33 WIB
} 
memberikan pekerjaan untuk para penyandang disabilitas sama halnya dengan mendorong perusahaan dalam jurang kebangkrutan karena harus rela menyediakan beberapa alat-alat bantu bagi kemudahan para penyandang disabilitas dalam menunjang aktivitasnya. Permasalahan yang dihadapi penyandang disabilitas tidak hanya sebatas "pelabelan" sebagai kaum yang berbeda sehubungan dengan kondisi jasmani yang disandangnya namun juga berkaitan dengan kesejahteraan sosial yang dihadapinya.

Dinas Sosial merupakan dinas yang mempunyai tugas untuk melaksanakan sebagian urusan pemerintahan daerah berdasarkan asas, otonomi dan tugas pembantuan di bidang sosial. ${ }^{3}$ Dinas Sosial selaku dinas yang menaungi masalah sosial harus mampu berperan secara maksimal untuk memberdayakan para penyandang disabilitas terutama yang telah memasuki tahap produktif dalam hidupnya. Sehingga selain dapat mengurangi beban dari keluarga, juga dapat mengurangi tingkat pengangguran dan tingkat pengemis di Kota Binjai, serta dapat meningkatkan taraf kemandirian penyandang disabilitas itu sendiri.

Pemberdayaan dari Dinas Sosial terhadap penyandang disabilitas salah satunya dengan cara mendayagunakan untuk dapat mengembangkan kemampuan yang dimiliki melalui pembinaan dan pelatihan yang intensif, sehingga mereka nantinya mempunyai bekal untuk hidup secara mandiri tanpa bergantung pada orang lain. Pemberdayaan bagi penyandang disabilitas merupakan suatu upaya untuk membantu meringankan beban dalam mencapai kesejahteraannya. Memberdayakan penyandang disabilitas dilakukan untuk meningkatkan harkat dan martabat penyandang disabilitas yang berada dalam kondisi lemah atau proses memampukan dan memandirikan disabilitas itu sendiri dengan mengandalkan kemampuannya sehingga dapat keluar dari perangkap kemiskinan dan keterbelakangan (Kartasasmita dalam Anwar, 2007:1)

Upaya kegiatan pemberdayaan yang dilaksanakan oleh Dinas Sosial Kota Binjai selaku instansi yang memang menangani masalah penyandang disabilitas berupa kegiatan pelatihan keterampilan. Terkait dengan uraian tersebut, kegiatan

${ }^{3}$ http://info.metrokota.go.id, diaksespadadiaksespadahariRabu, 20-03-2019, pukul 17:33 
pelatihan yang diberikan seharusnya tidak hanya diberikan setahun sekali, dan bentuk pelatihan yang diberikan juga harus diperluas tidak hanya dengan pelatihan keterampilan namun dapat berupa kegiatan pemberdayaan yang memberikan peluang atau akses yang lebih besar bagi penyandang disabilitas sesuai dengan minat dan bakat yang dimilikinya.

Menurut hasil pra-riset peneliti menemukan fakta bahwa pada usia diatas 18 tahun, ditemukan penyandang disabilitas yang mengemis dijalanan untuk mengharapkan sejumlah uang dari belas kasihan. Selain itu juga, peneliti menemukan bahwa penyandang disabilitas pada usia diatas 18 tahun yang mulai memasuki tahap produktif hanya berada di rumah, sehingga hanya menjadi beban tanggungan bagi keluarga. Berdasarkan urairan diatas, penulis tertarik untuk melakukan penelitian dengan "Peran Dinas Sosial Dalam Pemberdayaan Penyandang Disabilitas di Kota Binjai’.

\section{METODE PENELITIAN}

Penelitian ini dilaksanakan yang bertepatan di Binjai Kota. Alasan Penelitian memiliki lokasi ini adalah karena atas pertimbangan bahwa Dinas Sosial selaku dinas yang menaungi masaah sosial mempunyai tugas dan wewenang dalam proses pemberdayaan khususnya penyandang disabilitas sehingga peneliti merasa tertarik untuk melakukan penelitian di lokasi tersebut.

Penelitian tentang Peran Dinas Sosial Dalam Pemberdayaan Masyarakat ini menggunakan jenis Penelitian Kualitatif. Jenis penelitian ini yang digunakan untuk meneliti pada kondisi obyek yang alamiah. Pendekatan ini bertujuan untuk memahami suatu fenomena dalam konteks sosial secara alamiah dengan mengedepankan proses, dan juga penelitian ini bertujuan untuk memberikan deskripsi dari kebijakan yang dilakukan.

Instrumen dalam penelitian ini adalah sebagai berikut:

\section{Observasi}

Dalam penelitian ini, teknik observasi bersifat partisipan, yaitu pengamatan bagian dalam yang dilakukan oleh observer (peneliti) dengan ikut mengambil bagian dalam kehidupan orang-orang yang akan diobservasi. Teknik penelitian yang peneliti lakukan ini adalah langsung terjun kelokasi penelitian di Dinas 
Sosial Kota Binjai agar si peneliti dapat mengetahui aktifitas dan keseharian dari masyarakat sekitar yang akan diteliti.

Dalam hal ini penulis melakukan pengamatan berperan serta sebagai pengamat, yaitu peran peneliti sebagai pengamat dalam hal ini tidak sepenuhnya sebagai pemeran serta tetapi melakukan fungsi pengamatan. Yaitu sebagai anggota pura-pura, jadi tidak melebur dalam arti sesungguhnya. Peran demikian masih membatasi para subjek menyerahkan dan memberikan informasi terutama yang bersifat rahasia. Data yang diperoleh dari hasil observasi adalah gambaran tentang kondisi masyarakat Kota Binjai.

2. Interview atau Wawancara

Wawancara/interview adalah percakapan yang dilakukan dengan narasumber dengan maksud tertentu. Percakapan itu dilakukan oleh dua belah pihak yaitu pewawancara (interviewer) yang mengajukan pertanyaan kepada yang terwawancara yang memberikan jawaban atas pertanyaan itu. Dalam penelitian ini penulis menggunakan pendekatan dengan petunjuk umum wawancara, petunjuk wawancara hanyalah berisi petunjuk secara garis besar tentang proses dan isi wawancara untuk menjaga agar pokok-pokok yang direncanakan dapat seutuhnya tercakup. ${ }^{4}$

Tipe penelitian yang digunakan adalah deskriktif, dengan jenis data kualitatif yaitu data yang berbentuk kata-kata, kalimat, skema dan gambar. Penelitian deskriptif yaitu untuk membuat deskripsikan atau gambaran secara sistematis faktual dan akurat, mengenai fakta-fakta, sifat-sifat serta hubungan antara penomena yang diselidiki. ${ }^{5}$

Pengambilan data primer dilakukan dengan meneliti secara langsung ketika dinas sosial melakukan pemberdayaan terhadap penyandang disabilitas mereka. Dalam sumber data primer terdiri dari:

a. Kepala DINSOS Kota Binjai MPd

b. Sekretaris
: Drs. H. T. Syarifuddin, : Triono Julimawardi, S.Sos

\footnotetext{
${ }^{4}$ Sutrisno Hadi, Metodologi Research Jilid II (Yogyakarta: Andi Offset, 1989), hlm 136.

${ }^{5}$ Moloeng, Lexy, Metedologi Penelitian Kualitatif, Bandung (PT. Remaja Rosdakarya 2002), hlm. 211.
} 
c. Staf Dinas Sosial

d. Anak Penyandang Disabilitas
: Gunawan

: Ari Permana

Data Sekunder diperoleh melalui data pendukung yang berkaitan dengan penelitian berupa buku-buku, dokumentasi dan internet yang relevan dengan penelitian ini. Data yang dapat dianalisis menggunakan analisis data kualitatif model interaktif yang terdiri dari:

\section{Reduksi Data}

Reduksi data diartikan sebagai proses penelitian, pemusatan, pemerhatian pada penyederhanaan, pengabstrakan dan transformasi data yang muncul dari catatan tertulis dilapangan. Reduksi data berlangsung terus menerus selama penelitian berlangsung.

2. Penyajian Data

Penyajian data adalah sekumpulan informasi tersusun yang memberi kemungkinan adanya penarikan kesimpulan dan pengambilan tindakan.

3. Menarik Kesimpulan

Setelah data disajikan yang juga dalam rangkaian analisis data maka proses selanjutnya adalah penarikan kesimpulan atau verifikasi data. Proses verifikasi dalam hal ini adalah tinjauan ulang terhadap catatan lapangan. Data yang telah diperoleh dari catatan-catatan lapangan, dari informasi dan informan yang telah ditemukan, diuji kembali dengan menanyakan kembali pertanyaan yang sama diakhir penelitian dan melakukan wawancara kepada pengurus panti yang lain.

4. Triangulasi

Triangulasi adalah kombinasi beragam sumber data, tenaga penelitian, teori dan tehnik metodologis dalam suatu penelitian atas gejala sosial. Triangulasi diperlukan karena setiap teknik memiliki keunggulan dan kelemahannya sendiri. Pada tahap ini merupakan tahapan untuk mencari dan menata secara sitematis catatan hasil observasi, wawancara dan data pendukung lainnya untuk lebih memahamkan peneliti atas fenomena yang diteliti. ${ }^{6}$

${ }^{6}$ Lexy J. Moleong, Metodologi Penelitian Kualitatif EdisiRevisi (Bandung: PT. Remaja Rosdakarya, 2006), hlm 177. 


\section{HASIL PENELITIAN}

\section{Program Dinas Sosial dalam pemberdayaan penyandang disabilitas di Kota} Binjai.

Penyandang disabilitas sering dianggap tidak mampu melakukan kegiatan dan hanya menjadi beban bagi keluarga dan masyarakat, dikarenakan keterbatasan gerak mereka. Hal ini menimbulkan masalah mental dan sosial bagi penderitanya. Dinas sosial selaku pihak yang menaungi penyandang disabilitas mempunyai program yang terkait dengan memberikan bimbingan dan dukungan agar penyandang disablitas mampu menjalankan peran dan tugas kehidupannya sehingga tidak terjatuh dalam keadaan kondisi lemah dan terpinggirkan.

Selain itu program yang dibuat Dinas Sosial adalah memberikan kegiatan pelatihan berupa pelatihan keterampilan kuliner, seperti membuat ayam dan tahu goreng krispi serta pelatihan kerajinan tangan, seperti keterampilan mote-mote. Program tersebut dilaksanakan setiap 2 minggu sekali di setiap desa. Program selanjutnya yaitu Gebyar Kreatifitas Penyandang Disabilitas yang dilaksanakan satu tahun sekali. Program yang ditujukan untuk mengekspresikan kreatifitas dari dalam diri penyandang disablitas ersebut diikuti oleh penyandang disabilitas dengan kategori usia dari 4-18 tahun dan lebih dari 18 tahun ke atas.

Program tersebut berupa kegiatan penampilan karya seni mulai dari membaca puisi, tari yang samua pesertnya merupakan penyandang disabilitas. Ada pula kegiatan kerajinan yang ditampilkan dari penyandang disabilitas usia 18 tahun ke atas berupa kerjinan batik ciprat. Namun, program tesebut dinilai masih minim, terutama bagi penyandang disabilitas dalam usia produktif dikarenakan pada program yang diadakan untuk setiap satu tahun sekali ini belum mampu meningkatkan kesejahteraan mereka, dan program ini juga tidak dapat menajadi sumber mata pencaharian utama bagi para kaum penyandang disabilitas dalam memenuhi kebutuhan ekonomi mereka. ${ }^{7}$

\footnotetext{
${ }^{7}$ Wawancara kepada Bapak Lisbet Simaptupang S.Sos, Tanggal 13 Juni 2019, 10.00 di
} Dinas Sosial Kota Binjai 
Manfaat dari program Dinas Sosial dalam pemberdayaan penyandang disabilitas, yaitu antara lain:

1. Dinas Sosial selaku menaungi masalah sosial yg khususnya penyandang disabilitas sangat membantu penyandang disabilitas dalam kehidupan sehari-hari dengan adanya bimbingan dan keterampilan yang diberikan oleh pemerintah melalui tenaga ahli.

2. Perhatian dari Dinas Sosial yang cukup besar bagi penyandang disablitas dengan diterimanya di sekolah-sekolah yang khusus untuk mereka dan hampir disamakan dengan siswa lainnya,

3. Lapangan pekerjaan seamakin lebar bagi penyandang disabilitas bagi yang mempunyai keahlian/skill.

Program pemerintah ini sudah berjalan 4 tahun dengan banyak membantu penyandang disabilitas karena Dinas Sosial membantu rakyatnya seluas-luasnya melalui berbagai macam program pemberdayaan serta keterampilan yang sudah tertera. Dampak dari program Dinas Sosial dalam pemberdayan ini semakin banyak yang terbantu meskipun penyandang disabilitas setiap tahunnya terus bertambah tetapi dengan adanya program dari Dinas Sosial masyarakat disabilitas sangat terbantu dan bisa akan disejajarkan dengan manusia normal lainnya. Bila dilihat kemakmurannya masih jauh dari manusia normal lainnya karena penyandang disablitas perlu penyesuaian dalam keahliannya dengan manusia normal lainnya. Untuk itu perlu tenaga ahli yang turut membimbing agar bisa makmur kehidupannya seperti manusia normal lainnya.

\section{Bentuk Pemberdayaan Dinas Sosial terhadap Penyandang Disabilitas di Kota Binjai}

Bentuk pemberdayaan Dinas Sosial untuk mensejahterakan kaum yang lemah khususnya penyandang disabilitas sedikit banyak telah dilakukan oleh pemerintah maupun non pemerintah. Baik itu melalui peminjaman modal, pembinaan, pendidikan inklusi, pengembangan karakter, dan lain-lain. Hal tersebut merupakan salah satu bentuk upaya untuk memberdayakan penyandang disabilitas agar dapat mencapai kehidupan yang lebih baik. Terkait dengan pembinaan terhadap penyandang disabilitas, pemerintah bertugas untuk 
memfasilitasi, yang dimaksud memfasilitasi adalah bentuk memberdayakan melalui pemberian pedoman, bimbingan, pelatihan, arahan dan supervisi.

Harapan adanya pembinaan dan dukungan dari pemerintah daerah dan instansi terkait terhadap penyandang disabilitas ini hendaknya dapat terus dilakukan, agar kemandirian dan kesejahteraan dalam kehidupannya dapat terwujud kehidupan bermasyarakat dengan melalui partisipasi dari masyarakat yang bersangkutan agar tercipta kemampuan dan kekuasaan akan dirinya untuk aktif dan ikut andil dalam kehidupan sosial melalui penguatan kapasitas diri dengan memanfaatkan kemampuan yang ada sehingga tercipta kemandirian.

Tentu saja kegiatan pemberdayaan dilakukan demi terwujudnya taraf hidup yang lebih baik. Pada dasarnya setiap orang memiliki kemampuan untuk merubah kehidupannya, dari yang belum mampu menjadi mampu, belum berdaya menjadi berdaya dan lain-lain. Semua hal tersebut akan terlaksana dengan baik apabila masyarakat yang diberdayakan turut berpartisipasi aktif untuk melakukan perubahan yang nyata dalam kehidupannya. Pemberdayaan dilandasi oleh keadilan yang pada akhirnya akan meningkatkan kemampuan baik itu kemampuan fungsional, vokasional, pendidikan dan kemampuan sosialnya, rasa percaya diri serta kemandirian. ${ }^{8}$

Tabel 1 Jumlah Disabilitas

\begin{tabular}{|c|c|c|c|}
\hline NO & Kecamatan & Tahun 2016 & Tahun 2018 \\
\hline 1 & Binjai Utara & 75 & 76 \\
\hline 2 & Binjai Barat & 75 & 84 \\
\hline 3 & Binjai Timur & 71 & 82 \\
\hline 4 & Binjai Selatan & 46 & 47 \\
\hline & Jumlah & 267 & 289 \\
\hline
\end{tabular}

Sumber: Pra Riset Juni 2019

\footnotetext{
${ }^{8}$ Wawancara kepada Bapak Gunawan, Tanggal 20 Juni 2019, 19.00 WIB, di Rumah Bapak Gunawan
} 
Berdasarkan tabel diatas, rekapitulasi data dari Dinas Sosial pada tahun 2016 dan 2018 menunjukkan bahwa terjadi peningkatan jumlah penyandang disabilitas setiap tahunnya. Hal ini sudah seharusnya perlu menjadi perhatian khusus dan menjadi tanggung jawab bersama antara pihak pemerintah yang dalam hal ini melalui Dinas Sosial selaku intansi yang memang menaungi masalah penyandang disabilitas, serta masyarakat diskriminasi terhadap penyandang disabilitas dapat diminimalisir salah satunya melalui upaya pemberdayaan. Pemberdayaan dari Dinas Sosial terhadap penyandang disabilitas salah satunya dengan cara memberdayagunakan untuk dapat mengembangkan kemampuan yang dimiliki pembinaan dan pelatihan yang intensif, sehingga mereka nantinya mempunyai bekal untuk dapat hidup secara mandiri tanpa bergantung pada orang lain.

Upaya kegiatan pemberdayaan yang di laksanakan oleh Dinas Sosial Kota Binjai selaku instansi yang memang menaungi masalah penyandang disabilitas berupa kegiatan pelatihan keterampilan.

Tabel 2

Pelatihan Keterampilan bagi Penyandang Disabilitas Kota Binjai

\begin{tabular}{|c|c|c|c|c|}
\hline NO & Jenis Pelatihan & $\begin{array}{l}\text { Minggu } \\
\text { Pelatihan }\end{array}$ & $\begin{array}{l}\text { Jumlah } \\
\text { Peserta }\end{array}$ & Jenis Bantuan \\
\hline 1 & $\begin{array}{l}\text { Pelatihan } \\
\text { keterampilan } \\
\text { kuliner (ayam dan } \\
\text { tahu goreng krispi) }\end{array}$ & $\begin{array}{l}2 \text { minggu } \\
\text { sekali }\end{array}$ & 10 orang & $\begin{array}{ll}\text { - } & \text { Gerobak dagang } \\
\text { - } & \text { Kompor gas } \\
\text { - } & \text { Peralatan } \\
& \text { masak/peralatan } \\
& \text { menggoreng }\end{array}$ \\
\hline 2 & $\begin{array}{l}\text { Pelatihan } \\
\text { keterampilan mote- } \\
\text { mote }\end{array}$ & $\begin{array}{l}2 \text { minggu } \\
\text { sekali }\end{array}$ & 10 orang & $\begin{array}{l}\text { - } \text { Bahan membuat } \\
\text { mote-mote }\end{array}$ \\
\hline
\end{tabular}

Sumber: Pra Riset juli 2019, Dinas Sosial Kota Binjai di Bidang Sosial 
Terkait dengan data diatas, kegiatan pelatihan yang diberikan seyogyanya tidak hanya diberikan setiap 2 minggu sekali, dan bentuk pelatihan yang diberikan juga harus diperluas tidak hanya dengan pelatihan keterampilan namun dapat berupa kegiatan pemberdayaan yang memberikan peluang akses yang lebih besar bagi penyandang disabilitas sesuai dengan minat dan bakat yang dimilikinya. Pada setiap 2 minggu sekali jumlah peserta hanya terdiri 10 orang. Apabila di bandingkan dengan jumlah keseluruhan penyandang disabilitas di Kota Binjai, jumlah penyandang disabilitas yang diberikan pelatihan keterampilan tersebut sangat minim, jumlah tersebut bahkan tidak mencapai 20 persen dari jumlah keseluruhan penyandang disabilitas yakni 289 orang.

Peran Dinas Sosial dalam penanganan penyandang disabilitas masih terbatas. Keterbatasan sebagaimana terkait pada penanganan penyandang disabilitas yang tidak merata, sehingga masih terdapat penyandang yang belum tersenutuh penyuluhan/sosialisasi mengenai adanya pelatihan keterampilan, adanya bantuan sosial yang bertujuan untuk meningkatkan kemandirian penyandang disabilitas di Kota Binjai. Dinas Sosial selaku dinas yang menaunginya harus mampu berperan secara maksimal untuk memberdayakan para penyandang disabilitas terutama yang telah memasuki tahap produktif dalam hidupnya. Sehingga selain dapat mengurangi beban keluarga, juga dapat mengurangi tingkat pengangguran dan tingkat pengemis di Kota Binjai terutama, serta dapat meningkatkan taraf kemandirian penyandang disabilitas itu sendiri.

\section{A. Faktor penghambat Dinas Sosial dalam memberdayakan penyandang disabilitas sdi Kota Binjai.}

Yang termasuk faktor penghambat yaitu:

1. Banyaknya pemain (aktor) yang terlibat

Makin banyak pihak yang harus terlibat dalam mempengaruhi pelaksanaan program, karena komunikasi akan semakin rumit dalam pengambilan keputusan karena rumitnya komunikasi maka makin besar kemungkinan terjadinya hambatan dalam proses pelaksanaan.

1. Terdapatnya komitmen atau loyalitas ganda 
Dalam banyak kasus, pihak yang terlibat dalam menentukan suatu program, telah menyetujui suatu program tetapi dalam pelaksanaannya masih mengalami penundaan karena adanya komitmen terhadap program lainnya,

2. Kerumitan yang melekat pada program itu sendiri

Sering sebuah program mengalami kesulitan dalam pelaksanaannya karena sifat hakiki dari program itu sendiri. Hambatan yang melekat dapat berupa faktor teknis, faktor ekonomi, faktor perilaku pelaksana maupun masyarakat.

3. Jenjang pengambilan keputusan yang terlalu banyak

Makin banyak jenjang dan tempat pengambilan keputusan yang persetujuannya diperlukan sebelum rencana program dilakukan berarti makin banyak dibutuhkan untuk persiapan pelaksana program.

Hambatan-hambatan lainnya bagi penyandang disabilitas adalah:

1. Keterbatasan gerak dan langkah karena faktor fisik

2. Keterbatasan kemampuan karena tidak dapat leluasa bergerak dan berkarir

3. Kurangnya tenaga ahli yang selalu mendampingi dan membimbing bagi penyandang disabilitas.

4. Kurangnya lapangan pekerjaan karena masih terbatasnya kemampuan dan keahlian bagi penyandang disabilitas.

\section{PENUTUP}

\section{Kesimpulan}

Berdasarkan hasil dan pembahasan, maka peneliti menarik simpulan bahwa dalam pemberdayaan penyandang disabilitas telah melaksanakan perannya namun belum maksimal karena melihat dari segi jumlah penerima bantuan dari perannya yaitu peran fasilitatif yang dilaksanakan Dinas Sosial belum secara merata, dibuktikan dengan pelatihan dan bantuan sosial yang diberikan masih terbilang minim bahkan tidak mencapai 20 persen dari jumlah keseluruhan penyandang disabilitas di Kota Binjai yakni sebanyak 381 orang. 
Selain itu Dinas Sosial telah menjalankan perannya dalam memberdayakan penyandang disabilitas di Kota Binjai yaitu dengan memfasilitasi para penyandang disabilitas seperti memberikan bantuan berupa sembako dan bantuan kursi roda kepada penderita tuna daksa. Selain itu dari segi peningkatan pengetahuan keterampilan peran Dinas Sosial yakni dengan melakukan pelatihan seperti salon untuk 10 penyandang disabilitas, dan pijat untuk 10 penyandang tuna netra dengan mendatangkan ahli sebagai narasumber sekaligus instruktur bagi mereka.

Sehingga peran-peran yang dilakukan Dinas Sosial dalam memberdayakan penyandang disabilitas dari segi jumlah penerima bantuan sosial dapat dikatakan meningkat walaupun tidak dengan jumlah yang signifikan. Sedangkan dari segi pelatihan, peran yang dilakukan Dinas cukup baik walaupun tidak mengalami peningkatan. Hal ini dikarenakan jumlah peserta pelatihan yang hanya 10 orang selama 10-15 hari per-tahun dengan jenis pelatihan yang berbeda tiap tahunnya.

\section{DAFTAR PUSTAKA}

Ardiansyah, Darman, "Peran Dinas Sosial Provinsi Kepulauan Riau dalam Meningkatkan Kesejahteraan Sosial Penyandang Cacat Di Provinsi Kepulauan Riau", Skripsi (Kepulauan Riau, Fakultas Ilmu Sosial dan Ilmu Politik Universitas Maritim Raja Ali Haji, 2015).

Biro Hukum Depsos RI, Undang-undang RI NO.4 Tahun 1997

Brown, S. "Methodological Paradigms that Shape Disability Research" dalam Alberch,dkk.

Bungin, Burhan. 2007 Penelitian Kualitatif, Cet I; Jakarta: Kencana.http://carapedia.com/pengertiandefenisiperaninfo2184.html, diakses pada tanggal 20 Oktober 2018 pukul 20.57 WIB

Daming, Saharuddin. "Pelembagaan Penyandang Disabilitas sebagai Terminologi Baru Pengganti Istilah Penyandang Cacat" makalah Semiloka, (tidak diterbitkan, 2009)

Departemen Pendidikan dan Kebudayaan, 1998 Kamus Besar Bahasa Indonesia, Jakarta Balai Pustaka

Dokumen Salamnca di Spanyol tahun 1994 diselenggarakan di Unesco 
Fahir. Teori Peran dan Defenisi Peran Menurut Para Ahli,http://fahriblus.blogspot.com/2013/06/teori-peran-dan-defenisi-peran-menurut.html, diakses pada tanggal 20 Oktober 2018 pukul 21.17

Fahir. Teori Peran dan Defenisi Peran Menurut Para Ahli,http://fahriblus.blogspot.com/2013/06/teori-peran-dan-defenisi-peran-menurut.html, diakses pada tanggal 20 Oktober 2018 pukul 21.17

Handbook of Disability Studies, (London:Sage), dalam Ro'fah dkk, Membangun Kampus Inklusif, (Yogyakarta:PLSD UIN Sunan Kalijaga, 2010)

http://carapedia.com/pengertiandefenisiperaninfo2184.html, diakses pada tanggal 20 Oktober 2018 pukul 20.57 WIB

http://dinsos.jogjaprov.go.id/tugas-dan-fungsi, diakses tanggal 20-10-2018, pukul 23.00 wib http://id.wikipedia.org /wiki/Pemberdayaan_Masyarakat, diakses tanggal 19-10-2018/pukul $20.00 \mathrm{wib}$

http://dinsos.jogjaprov.go.id/tugas-dan-fungsi, diakses tanggal 20-10-2018, pukul 23.00 wib

http://id.wikipedia.org /wiki/Pemberdayaan_Masyarakat, diakses tanggal 19-102018/pukul $20.00 \mathrm{wib}$

http://repository.usu.ac.id/bitstream/handle/123456789/51408/Chapter\%2011.pdf?

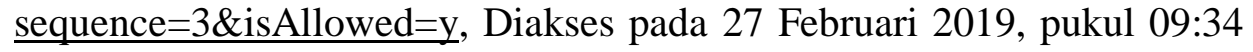
Wib

https://www.banyuwangikab.go.id/skpd/unit/10601/dinas-sosial.html, diakses tanggal 19-10-2018/pukul 22.30

Husain Usman dan Purnomo Setiadi Akbar, 2001 Metode Penelitian Sosial, Cet. IV; Jakarta: PT. Bumi Aksara.

Imam Suprayogo, 2003 Metodologi Penelitian Sosial Agama, Bandung: Remaja Rosdakarya.

Jim Ife dan Frank Tesoriero, 2008 Community Development, Yogyakarta: Pustaka Pelajar, 2008

Kemensekneg RI, Lembaran Negara RI Tahun 2011 Nomor 107, Lampiran UU RI Nomor 19 Tahun 2011 tentang Convention on the Right of Persons with Disabilities (Konvensi Hak-hak Penyandang Disabilitas) Pasal1

Mikkelsen, Brita, Metode Penelitian Partisipatoris dan Upaya Pemberdayaan, (Jakarta: Yayasan Pustaka Obor Indonesia, 2011)

Moloeng, dkk. 2002 Metedologi Penelitian Kualitatif, Bandung PT. Remaja Rosdakarya. 
Ar-Rifa'i, Muhammad, Ringkasan Tafsir Ibnu Katsir, Jilid 2, Cetakan ke-2, (Jakarta:Gema Insani, 2007)

Muslim, Aziz. 2009 Metodologi Pengembang Masyarakat, Yogyakarta, Penerbit TERAS.

Muslim, Aziz. 2012 Dasar-Dasar Pengembangan Masyarakat, Yogyakarta: Samudra Biru.

Poerwadaminta, 1990 Kamus Umum Bahasa Indonesia Jakarta

Poerwadaminta, Kamus Umum Bahasa Indonesia (Jakarta:1990)

Pratiwi, Gusti Indah. "Peran Pemerintah dalam Perlindungan Sosial Penyandang Disabilitas Di Pekanbaru”. Jurnal (Fakultas Ilmu Sosial dan Politik, Universitas Islam Riau, 2016).

Pusat Pembinaan dan Pengembangan Bangsa, 1989 Kamus Besar Bahasa Indonesia, Jakarta: Balai Pustaka

Rukminto Adi, Isbandi. 2002 Pemikiran-pemikiran dalam Pembangunan Kesejahtreaan Sosial, Jakarta: LP FEUI.

S. Nasution. 2008 Metode Research, Penelitian Ilmiah, Cet. X; Jakarta: Bumi Aksara.

Soeharto, Edi. Membangun Masyarakat Memberdayakan

Soekanto, Soejono. 1997 Sosiologi Suatu Pengantar, Jakarta: Yayasan Penerbit UI

Sugiono. 2006 Metode Penelitian Administrasi Cet, XIV; Jakarta: CV. Alfabeta.

Suharsimi, Arikunto. 2006 Prosedur Penelitian suatu Pendekatan Praktik, Jakarta: PT Rineka cipta.

Suharto, Edi. Membangun Masyarakat Memberdayakan Rakyat Kajian Strategis Pembangunan Kesejahteraan Sosial dan Pekerjaan Sosial, 2005 Bandung: PT. Revika Aditama.

Suprayogo, Imam 2003 Metodologi Penelitian Sosial Agama, Bandung: Remaja Rosdakarya.

T. Sutjihati Somantri, Psikologi Anak Luar Biasa, (Jakarta:Refika Aditama,2006),hlm:65-66

S

Universitas Islam Indonesia, Al-Qur'an dan Tafsirnya, (Yogyakarta: PT. Dana Bakti Wakaf, 1995)

Wikipedia Kamus Ensiklopedia", diunduh dari http//id.wikipedia.org/wiki/anak berkebutuhan 
khusus tanggal 06 Februari 2019.

Zubaedi, Pengembangan Masyarakat, (Jakarta:2013)Mikkelsen, Brita, Metode Penelitian Partisipatoris dan Upaya Pemberdayaan, (Jakarta: Yayasan Pustaka Obor Indonesia, 2011)

Zubaedi. 2013 Pengembangan Masyarakat Wacana \&Praktis, Jakarta: Kencana Prenada Media Group,2013 